\title{
The ubiquitin-proteasome system in regulation of the skeletal muscle homeostasis and atrophy: from basic science to disorders
}

Yasuo Kitajima ${ }^{1^{*}} \mathbb{D}$, Kiyoshi Yoshioka ${ }^{2}$ and Naoki Suzuki $i^{3,4^{*}}$

\begin{abstract}
Skeletal muscle is one of the most abundant and highly plastic tissues. The ubiquitin-proteasome system (UPS) is recognised as a major intracellular protein degradation system, and its function is important for muscle homeostasis and health. Although UPS plays an essential role in protein degradation during muscle atrophy, leading to the loss of muscle mass and strength, its deficit negatively impacts muscle homeostasis and leads to the occurrence of several pathological phenotypes. A growing number of studies have linked UPS impairment not only to matured muscle fibre degeneration and weakness, but also to muscle stem cells and deficiency in regeneration. Emerging evidence suggests possible links between abnormal UPS regulation and several types of muscle diseases. Therefore, understanding of the role of UPS in skeletal muscle may provide novel therapeutic insights to counteract muscle wasting, and various muscle diseases. In this review, we focussed on the role of proteasomes in skeletal muscle and its regeneration, including a brief explanation of the structure of proteasomes. In addition, we summarised the recent findings on several diseases and elaborated on how the UPS is related to their pathological states.
\end{abstract}

Keywords: Ubiquitin proteasome system, Muscle homeostasis, Muscle stem cell, Myopathy, Muscular dystrophy, Cachexia, Amyotrophic lateral sclerosis

\section{Introduction}

The skeletal muscle mass accounts for approximately $40 \%$ of the total human body weight, making it the largest tissue mass present in the body [1]. Maintaining muscle homeostasis is essential for preserving the body's integrity and activities of daily living, and thus, muscle loss or impairment is associated with several diseases, which ultimately leads to a poor quality of life. Skeletal muscle is highly plastic tissue, and its mass can change dynamically. Muscle atrophy is caused by an imbalance in

\footnotetext{
*Correspondence: kitajima-y@kumamoto-u.ac.jp; naoki@med.tohoku.ac.jp ${ }^{1}$ Department of Muscle Development and Regeneration, Institute of Molecular Embryology and Genetics, Kumamoto University, 2-2-1 Honjo, Kumamoto 860-0811, Japan

${ }^{3}$ Department of Neurology, Tohoku University School of Medicine, 1-1 Seiryo-machi, Aoba-ku, Sendai 980-8574, Japan

Full list of author information is available at the end of the article
}

proteostasis; during muscle atrophy, protein degradation overwhelms protein synthesis, leading to loss of muscle mass and muscle weakness. Paradoxically, in general, proteolysis is critical for preventing cellular dysfunction and the progression of diseases, causing complexity of proteolysis in skeletal muscle.

Perhaps the ubiquitin-proteasome system (UPS) is the most well-known cellular proteolytic system, which is responsible for degrading majority of the misfolded or defective cellular proteins [2]. Most proteins undergo degradation by being the target of the $26 \mathrm{~S}$ proteasome through covalent attachment of a multi-ubiquitin chain. The ubiquitination of proteins involves the action of the E1 ubiquitin-activating enzyme, E2 ubiquitin-conjugating enzymes, and E3 ubiquitin-protein ligases. These tagged proteins are then recognised by the $26 \mathrm{~S}$ proteasome, consisting of a central barrel-shaped $20 \mathrm{~S}$ core associated 
with two 19S regulatory subunits [3, 4]. The latter subunits recognise and bind to the ubiquitinated proteins and initiate the adenosine triphosphate (ATP)-dependent degradation process within the catalytic core [3]. Using such a mechanism above, the UPS performs substratespecific proteolysis.

Although there remains a lot to understand how the UPS recognises misfolded or defective proteins, disruption of the UPS is associated with pathological states, highlighting the importance of this system in cellular and whole-body homeostasis. Accordingly, several reports have demonstrated a relationship between proteasome system and lifespan. Proteasome activity has been reported to decrease with age in the brain [5], liver [6, 7], heart [8], and skeletal muscles [9], causing age-associated deteriorations. On the other hand, the genetical activation of the proteasome in yeast and Caenorhabditis elegans show protective effect against cellular aging and prolonged lifespan [10,11].

It has also been shown that the overexpression of proteasome subunits in yeast and Caenorhabditis elegans results in an increase in the proteasome activity and leads to a prolonged lifespan $[10,11]$. Conversely, transgenic mice constitutively expressing the $\beta 5$ t subunit of the proteasome showed reduced proteasome activity and a shorter lifespan [12]. Moreover, the loss of function of the Rpn11 subunit of the proteasome results in decreased proteasome activity, accumulation of ubiquitinated proteins, and a shortened lifespan [13]. These previous studies suggest that continuous clearance of misfolded proteins mediated by the UPS is necessary for healthy aging. We recently reported that skeletal muscle-specific reduction in proteasome activity is associated with a shortened lifespan in mouse models $[14,15]$. Thus, the UPS in skeletal muscle, which comprises the largest mass in the body, may have a strong impact on aging, longevity, and whole-body homeostasis.

Proteolysis in skeletal muscle has dual nature: proteolytic pathways play a substantial physiological role in muscle atrophy, while their inhibition also promotes muscle dysfunction and weakness [16]. Indeed, contrary to the protective role of the UPS in maintaining cellular functions, many studies also have implicated that the UPS promotes muscle wasting, myofibre degeneration, and muscle weakness. Skeletal muscles function as a storage place for amino acids, and it might be one reason for the disuse atrophy. These contradictions result in variable effects of inhibitions of UPS in atrophies. Therefore, better understanding of the pathogenic role of this proteolytic system in skeletal muscle may provide novel therapeutic insights to counteract the UPS-associated diseases.
In this manuscript, we reviewed published important articles about UPS in the sequence of molecules, myotubes, skeletal muscles, until muscle atrophy in the patients. We focussed on the role of the UPS in skeletal muscle, by outlining the results of our recent studies on proteasomes in skeletal muscle and muscle stem cells. We further summarised recent findings on several diseases, and elaborated on how the UPS is related to their pathological states.

\section{Structure of the 265 proteasome}

Proteolysis by the UPS is mainly performed through a series of complex structures. The rapid degradation of ubiquitinated proteins by the $26 \mathrm{~S}$ proteasome involves multiple enzymatic and non-enzymatic steps. The $26 \mathrm{~S}$ proteasome is a multi-catalytic protease localised both in the nucleus and cytoplasm. As shown in Fig. 1, it is composed of one proteolytically active cylinder-shaped particle (the $20 \mathrm{~S}$ proteasome), and two ATPase-containing

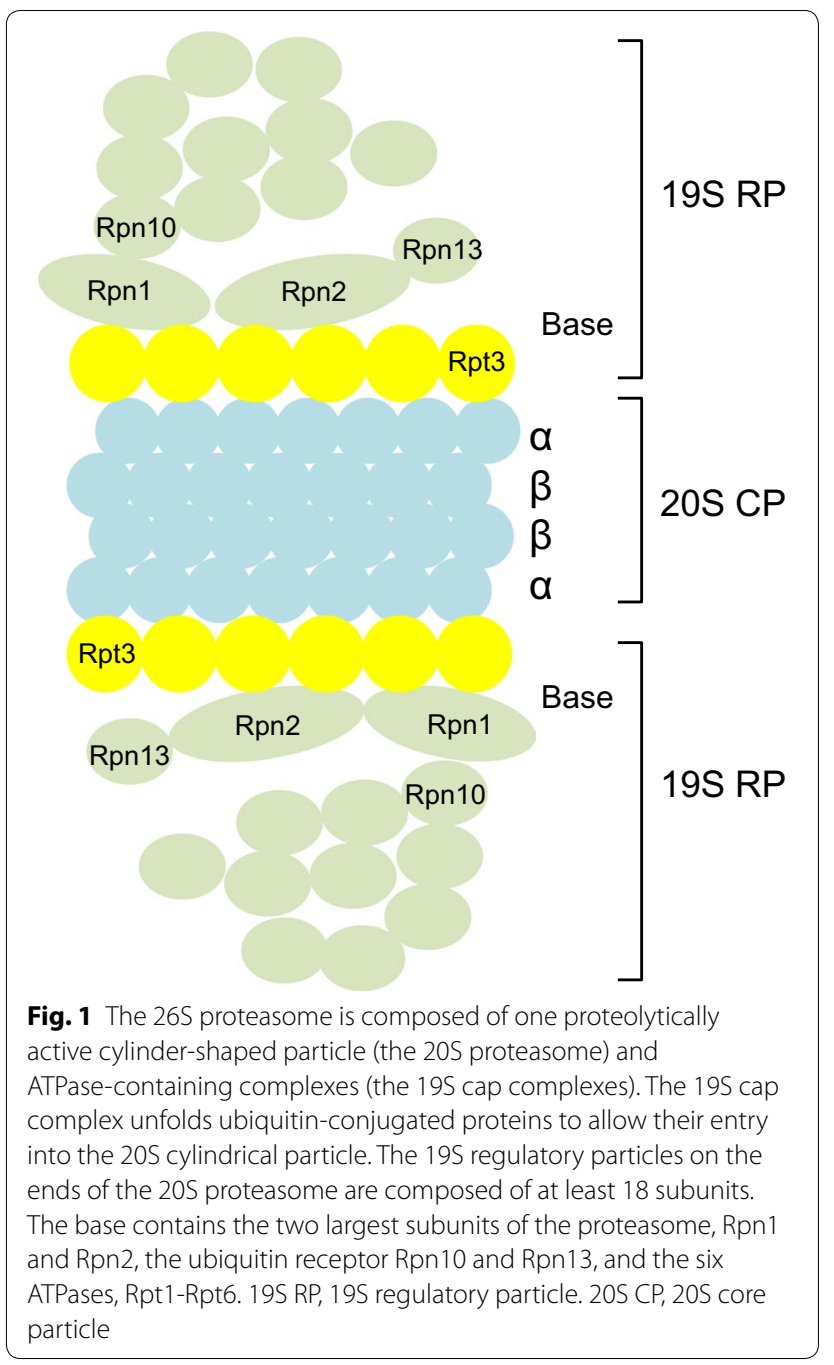


complexes (known as the 19S cap complexes) [3, 4, 17]. The 19S cap complexes unfold the ubiquitin-conjugated proteins, allowing them to enter into the $20 \mathrm{~S}$ core particle. The $20 \mathrm{~S}$ core is composed of inner $\alpha$-rings and outer $\beta$-rings, each of them has seven structurally similar subunits, respectively; $\alpha 1-7$ and $\beta 1-7$ [18]. In particular, $\beta 1$, $\beta 2$, and $\beta 5$ subunits display caspase-like, trypsin-like, and chymotrypsin-like proteasome activity, respectively $[19,20]$. Also, these $\beta$ subunits contain immunoproteasomes, in which $\beta 1, \beta 2, \beta 5$ subunits are replaced with $\beta 1 \mathrm{i}$ (LMP2), $\beta 2 \mathrm{i}$ (MECL1), $\beta 5 \mathrm{i}$ (LMP7) subunits, respectively. Recently, an association between the immunoproteasome and disease has been reported and is described in Sect. 4.2.1. The $19 \mathrm{~S}$ regulatory particles are composed of at least 18 subunits $[3,4]$. Two components form the $19 \mathrm{~S}$ proteasome, the lid and the base. The lid, which is responsible for the recognition of the polyubiquitin signal [21, 22], is composed of nine subunits, Rpn3, Rpn5-9, Rpn11-12, and Rpn15. The base is composed of the two largest subunits of the proteasome, Rpn1 (PSMD2) and Rpn2 (PSMD1), the ubiquitin receptor Rpn13, Rpn10 (PSMD4), and six ATPases, Rpt1-Rpt6 (PSMC2, PSMC1, PSMC4, PSMC6, PSMC3, PSMC5, respectively). These subunits form a large family of proteins with a highly conserved ATPase domain [23]. Rpt3, also known as PSMC4, is an essential subunit of the $26 \mathrm{~S}$ proteasome [23] and is required for the degradation of most proteasomal substrates. The ubiquitin receptor Rpn10 attaches to Rpn1, although this association is stabilised by presence of Rpn2 [24]. Rpn2 acts as a receptor of the ubiquitin receptor Rpn13 [25-27].

\section{Protein degradation in the skeletal muscle E3 ubiquitin ligases and UPS in skeletal muscle}

Muscle atrophy is a serious problem that limits the daily activities and reduces the quality of life. Regulation of the skeletal muscle mass is highly dependent on both the protein synthesis and protein degradation processes. Proteolysis in skeletal muscle is closely regulated by ubiquitin ligases. In skeletal muscle, Cullin-RING ubiquitin ligases comprise the largest known category of ubiquitin ligases as shown in Table 1. Cullin-RING ubiquitin ligases regulate various cellular processes, including multiple aspects of the cell proliferation, transcription, signal transduction, and development [28]. Especially, the muscle-specific E3 ubiquitin ligases, such as the muscle RING finger 1 (MuRF1) and the muscle atrophy F-Box (Atrogin-1/MAFbx), are involved in the regulation of protein degradation in skeletal muscle [29-31]. The expression of these two ubiquitin ligases has been shown to markedly increase in skeletal muscle atrophy [32, 33]. Studies have suggested that titin, Myosin Heavy Chains, Myosin Light Chain-1/2 as the substrates of MuRF1 and
Table 1 Ubiquitin ligases related with UPS in skeletal muscles modified from Ref. [82]

\begin{tabular}{lll}
\hline Ubiquitin ligases & Target or affected proteins & Refs. \\
\hline MuRF1 (TRIM63) & $\begin{array}{l}\text { Sarcomeric proteins, myosin-binding } \\
\text { protein (MYBPC1), troponin 3, tel- }\end{array}$ & {$[83-86]$} \\
& $\begin{array}{l}\text { ethonin } \\
\text { MuRF3 (TRIM 54) }\end{array}$ & Sarcomeric proteins, filamin \\
TRIM32 & Actin, desmin & {$[83,87]$} \\
MUSA1 & - & {$[88]$} \\
SMART & - & {$[37]$} \\
Nedd4 & MTMR4, FGFR1, Notch 1 & {$[37,38]$} \\
TRAF6 & Ubc13, K63-linked ubiquitination & {$[89,90]$} \\
Cullin adaptors & & {$[128-130]$} \\
Atrogin-1/MAFbx & Actin, titin, calsarcin-1, MYHBPC3 & {$[91,92]$} \\
Cbl-b & Insulin receptor substrate 1 (IRS-1) & {$[35,36]$} \\
KLHL40 & Filament protein & {$[95]$} \\
KBTBD13 & Z-disc proteins & {$[96]$} \\
KLHL41 & Nebulin, nebulin-related anchoring & {$[97-99]$} \\
KLHL20 & protein & {$[100,101]$} \\
\hline
\end{tabular}

MURF1: muscle RING finger 1; MuRF3: muscle RING finger 3; TRAF6: tumour necrosis factor receptor-associated factor 6; Cbl-b: Casitas B-lineage lymphoma proto-oncogene-b; KLHL40: Kelch-like protein 40; KLHL41: Kelch-like protein 41; KLHL20: Kelch-like protein 20

elongation initiation factor 3 subunit $\mathrm{f}$ (eIF3-f), MyoD, and myogenin as the substrates of Atrogin-1/MAFbx [34]. Although their specific substrate in vivo is yet to be elucidated, MuRF1 or Atrogin-1/MAFbx knockout mice are resistant to muscle atrophy induced by denervation [32], suggesting that these two genes are important regulators of muscle atrophy.

In addition to MuRF1 and Atrogin-1/MAFbx, Casitas B-lineage lymphoma proto-oncogene-b (Cbl-b) is also a known E3-ligase related to muscle atrophy. Unloading or spaceflight promotes the expression of Cbl-b; which targets IRS-1, an intermediate of IGF-I signalling which induces protein synthesis in muscle. Thus, it seems Cblb, at least partly, works as mechanosensing-mediated muscle atrophy [35, 36]. There are E3-ligases associated with denervation-induced muscle atrophy: muscle ubiquitin ligase of SCF complex atrophy-1 (MUSA1) and specific for muscle atrophy and regulated by transcription (SMART) [37, 38]. Moreover, Hughes et al. recently reported that an E3-ligase, F-box and leucine-rich protein 22 (Fbxl22) mediates neural inactivity-induced muscle atrophy [39]. Knockdown of Fbxl22 in denervated muscle resulted in significant muscle sparing. The expression of ubiquitin ligase is regulated by a transcription factor, Forkhead box O (FoxO) [30]. Akt phosphorylates FoxOs, thereby resulting in their export from the nucleus to the cytoplasm. On the other hand, when the Akt pathway is attenuated by models of muscle atrophy, FoxOs are 
imported to the nucleus and induce the expression of ubiquitin ligases. Although most of the E3-ligases remain to be explored in the context of muscle atrophy, these findings indicate that the UPS plays a substantial role in muscle atrophies.

\section{UPS dysfunction causes skeletal muscle atrophy}

The UPS degrades most of the long- and short-lived normal as well as abnormal intracellular proteins [40]. Especially in the muscle, most of the myofibrillar proteins are degraded through the UPS [41, 42]. We generated muscle-specific Rpt3-knockout mice (Mlc1f-Cre;Rpt3 ${ }^{\mathrm{f} / \mathrm{f}}$ ) to better understand the role of the proteasomal system in the skeletal muscle tissue. The proteasomal subunit Rpt3 deletion significantly decreases protease activities and increases ubiquitinated proteins [14]. The musclespecific deletion of Rpt3 resulted in reduced physical activity, and a decrease in the force production in mice, accompanied with the accumulation of abnormal proteins [14]. In addition, in muscle-specific Rpt3-deficient mice, muscle weight divided by body weight was significantly smaller in the gastrocnemius and tibialis anterior muscles, which are predominantly type II fibres, but not in the soleus muscle, which is predominantly type I fibres [14]. Previous studies have reported that type II glycolytic muscle fibres are more susceptible to muscle wasting conditions than are type I oxidative fibres $[43,44]$. Since genetic induction of PGC- $1 \alpha$ shows resistance to atrophy [45], the pro-atrophic response in type II fibres may be partly due to a low content of PGC1 $\alpha$. Interestingly, the proteasome-deficient mice showed premature death [14], where it further shows the importance of skeletal muscle homeostasis maintained by the UPS.

\section{Crosstalk with autophagy system in muscle-specific proteasome dysfunction}

Another degradation process, which is known as autophagy is the natural regulatory cellular mechanism that is mainly involved in the removal of unnecessary or dysfunctional components from the cell [46]. Autophagic process initiates by forming a flat membrane cistern that envelops a portion of cytoplasm, eventually forming a closed double-membrane vesicle, which is known as the autophagosome. The autophagosome further fuses with the lysosome where its cargo components are degraded. Although autophagy is marginally activated in basal conditions, main factor responsible for the activation is the nutrient starvation $[46,47]$. It has also been shown that mice deficient in Atg3, Atg5, or Atg7, which are involved in autophagy, respectively, appear almost normal at birth but die on the first day of birth [48-50].

Autophagy is also shown to be essential for the maintenance of the skeletal muscle homeostasis. With regard to the skeletal muscle, the excessive activation of autophagy promotes muscle wasting [51-53]. Conversely, the muscle-specific deletion of a crucial autophagy gene, Atg7, results in profound muscle atrophy and age-dependent decrease in the generation of muscle force [54]. Furthermore, when mTORC1 was constitutively activated in skeletal muscle by TSC1-knockout, autophagy is inhibited, and results in late onset severe myopathy [55]. Thus, autophagy plays an important role in muscle plasticity and homeostasis.

Since the UPS and autophagy pathways are differently oriented, these two proteolysis systems were viewed as independent $[56,57]$. However, there are emerging evidences suggesting the occurrence of a crosstalk between the autophagy and proteasomal pathways in the skeletal muscle. Although autophagy had been thought as a non-specific degradation system, it was found to degrade ubiquitinated proteins [58]. Moreover, muscle-specific autophagy dysfunction induces an increase in ubiquitinated proteins during denervation [54], which would be compensatory upregulation of UPS. Our previous study [14] also suggests the autophagy-UPS complementary relationship. Proteasome-deficient mice exhibited the activation of autophagy. Briefly, the protein levels of LC3II, a standard marker for autophagosomes, and ubiquitin-binding p62 were found to be increased in the Rpt3-/- gastrocnemius muscle. Moreover, the levels of Beclin-1 and Atg5 that are involved in the formation of the isolation membrane, and LC3I, which is involved in the initiation of autophagosome formation, were increased in the Rpt3-/- muscle. Therefore, the autophagy pathway seems to be enhanced in the UPS-deficient muscle. Previous studies also have demonstrated that inhibition of the UPS induces autophagy in vivo and in vitro $[59,60]$. Taken together, the UPS and autophagy systems, at least in part, compensatory maintain myocellular homeostasis and integrity.

\section{UPS in muscle stem cells and regeneration}

The adult muscle stem cells (also known as satellite cells) are required for the regeneration of the adult skeletal muscle [61]. Responding to muscle damage, satellite cells are rapidly activated and start to proliferate. Three days after the cardiotoxin injection-induced muscle damage, when the satellite cells are under the process of muscle regeneration, we found that both chymotrypsin-like and trypsin-like proteasome activities were increased. Using satellite cell-specific proteasome-deficient mice (Pax7CreERT2; Rpt ${ }^{\mathrm{f} / \mathrm{f}}$ ), we demonstrated that proteasome dysfunction impaired satellite cell ability to proliferate, survive, and differentiate, resulting in defective muscle regeneration [62] (Fig. 2). These findings indicate that the UPS activity in satellite cell is associated with muscle 


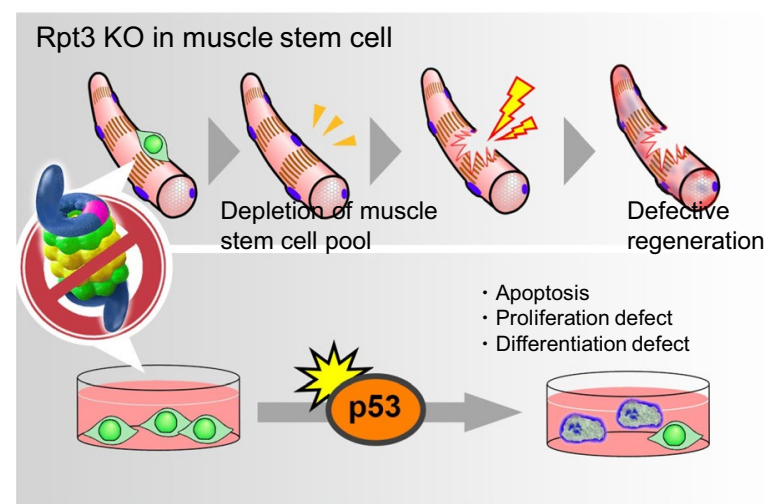

Fig. 2 Proteasome dysfunction in Rpt3-deficient muscle stem cells impaired their ability to proliferate, survive and differentiate, resulting in defective muscle regeneration. We also found that proteasome inactivation by Rpt3 deficiency in primary myoblasts inhibits cell proliferation and induces apoptosis. Further, proteasome dysfunction conferred by satellite cell-specific Rpt3-knockout induces p53 activation

regeneration, especially in the early phase [62]. Consistently, in a previous study, proteasome activity was found to be strongly correlated with proliferating cell nuclear antigen protein levels, suggesting that proteasomes play a key role in satellite cell proliferation [63]. Therefore, the findings suggest that the enhancement of the proteasome system is important for satellite cell proliferation and normal muscle regeneration.

Previous studies have also reported that the UPS is associated with the process of myogenic differentiation of satellite cells, which begins with cell cycle arrest and ends with the fusion of individual cells to form multinucleated myotubes [64-66]. In addition, it has also been shown that the inhibition or knockdown of the proteasome can block the fusion of myoblasts and thereby inhibit the process of differentiation $[65,66]$.

A lot of uncertainty still remains, regarding the relationship between the UPS and muscle regeneration. One possible candidate to explain the relationship would be $\mathrm{p} 53$, which regulates apoptosis and cell survival, and promotes muscle differentiation in myoblasts [67-71]. A recent study reported that the tight control of p53 levels in myoblasts regulates the balance between the differentiation process and the return to the quiescence stage [72], which indicates the importance of the p53 during the process of myogenic differentiation. Interestingly, p53 was upregulated in Rpt3-deficient primary satellite cells and the inhibition of p53 expression by siRNA in those cells reduced cell death [62]. These data indicate that Rpt3 in satellite cells is important for cell survival via p53. There is still ambiguity with regard to muscle regeneration and the UPS. Although further work needs to be carried out to understand the UPS, recent studies have revealed a link between the UPS and various diseases discussed the following section.

\section{Proteasome system and related diseases}

As the UPS is important for the maintenance of the homeostasis in skeletal muscle, dysfunctions in the system may lead to pathological conditions such as muscular dystrophy, myositis, cachexia and amyotrophic lateral sclerosis.

\section{Diseases with disorganisation of skeletal muscle itself Muscular dystrophy: aberrant developmental process}

Dystrophin, a $427-\mathrm{kDa}$ skeletal muscle protein, links the interior of the myofibres to the extracellular matrix. Mutations in the dystrophin gene are linked to a severe form of muscular dystrophy known as Duchenne muscular dystrophy (DMD) or a mild form known as Becker muscular dystrophy (BMD) [73]. Dystrophin missense mutations cause a wide range of severe phenotypical features in DMD patients. When these missense mutations are stably expressed in mammalian myoblasts, dystrophin proteins are unstable and the protein levels are decreased by proteasomal degradation, but still mutated dystrophin functions to some extent [74]. Continuous administration of the proteasomal inhibitor MG-132 effectively rescues the plasma membrane localisation and the amount of dystrophin in skeletal muscle fibres in dystrophin-deficient model mice [75]. Proteasomal inhibitors have been shown to reduce muscle membrane damage, as revealed by vital staining of the diaphragm and gastrocnemius muscle isolated from treated mice with dystrophin deficiency [75]. Bortezomib, which is a proteasome inhibitor, restores dystrophin and dystrophin-glycoprotein complex at the sarcolemma, which improves the dystrophic phenotype [76]. Compared with control animals, muscular dystrophy dogs treated with bortezomib had lower amount of connective tissue deposition and inflammation as evidenced by muscle histology, collagen morphometry, and ultrastructural microscopy [77].

Congenital muscular dystrophy, which is caused by mutations in the gene encoding the laminin $\alpha 2$ chain, is a severe and incapacitating disease [78]. Proteasome activity is increased in laminin $\alpha 2$ chain-deficient muscle, and treatment with MG-132 reduces muscle pathology in laminin $\alpha 2$ chain-deficient mice [78]. In addition, bortezomib reduces proteasome activity in congenital muscular dystrophy type 1A myoblasts and myotubes [78]. Hence, proteasome inhibition might be useful in patients lacking the laminin $\alpha 2$ chain as a supportive treatment [79]. In case of dysferlinopathy, it was reported that 
proteasomal inhibition restores biological function of missense mutated dysferlin in patient-derived cells, but the paper was retracted [80]. The effect of proteasome inhibition in muscular dystrophy is yet to be elucidated.

Overall, proteasome inhibition might block the degradation of the mutant dystrophin and recover the function to some extent.

\section{Disease related to mutants in the proteins of UPS system: abnormal maintenance of muscle structures}

Protein aggregate myopathies are characterised by protein accumulation in myofibres. These myofibres contain inclusions of sarcomere proteins including myosin and myosin-associated proteins with aberrantly distributed microtubules [81]. Since sarcomere proteins are degraded by UPS, UPS dysfunction might be central to the development of these diseases. It is important to understand how genetic mutations of UPS impact on sarcomere integrity.

Several disease-causing mutations have been found in ubiquitin E3-ligase and its adaptors (Table1) [82]. The genes tripartite motif-containing 63 and 54 (TRIM63 and TRIM54) encoding MuRF1 and MuRF3, respectively, are RING ubiquitin ligases involved in UPS. Both MuRFs are microtubule-associated proteins located in the $M$ bands and $\mathrm{Z}$ discs of the sarcomere [83]. These E3 ubiquitin ligases play a role in the degradation of sarcomeric proteins, myogenesis, and stabilisation of microtubules. The targets of MuRF1 include myosin-binding protein (MYBPC1), troponin 3, and telethonin, which cause distal arthrogryposis-1B myopathy [84], dilated cardiomyopathy-2A [85], and limb-girdle muscular dystrophy (LGMD)-7 [86], respectively. MuRF3 targets filamin, and MuRF3 mutations are associated with distal myopathy, myofibrillar myopathy, and restrictive cardiomyopathy- 5 [87]. Another TRIM protein, TRIM32, targets actin, and desmin. A mutation in TRIM32 results in LGMD, nemaline myopathy, or myofibrillar myopathy [88]. The ubiquitin ligase Nedd4 participates in denervation-induced muscle atrophy in mice [89], and a relationship between myotonic dystrophy type 2 and NEDD4 has also been reported in human [90]. Atrogin-1/MAFbx is the Cullin adaptor of UPS. Atrogin-1 targets actin and disconnects actin, titin, and calsarcin-1 [91]. Atrogin-1 also targets MYHBPC3, and mutation in the gene results in dilated cardiomyopathy [92].

The Kelch-like family members, the adaptor proteins of E3-ligase, are mutated in nemaline myopathy [93]. Mutations in the Kelch family affect Cullin 3 (CUL3) interaction, which in turn affects the ubiquitination and degradation of protein substrates targeted by CUL3 protein complex [94]. Several genes among the Kelch-like family members are involved in nemaline myopathy;
Kelch-like protein 40 (KLHL40) decreases thin filament protein stability [95], KBTBD13 disorganises the Z-disc [96], and Kelch-like protein 41 (KLHL41) impacts on nebulin degradation [97, 98]. KLHL41 degrades nebulin-related anchoring protein, and this degradation is dysregulated in nemaline myopathy [99]. Especially, the CUL3 and KLHL20 complex coordinates the amount of autophagy-related protein 13 (ATG13) in prolonged starvation and controls autophagy [100, 101].

Overall, mutations in several E3-ligases can be the cause of muscle diseases. Ubiquitin ligases could mediate the interplay between autophagy and ubiquitin proteasomal degradation.

\section{Cachexia: reduced stress tolerance of the skeletal muscle}

Cachexia reflects muscle wasting syndromes associated with several chronic diseases, such as cancer, diabetes, chronic obstructive pulmonary disease, congestive heart failure and chronic kidney disease (CKD) [102]. Body weight loss, muscle wasting, adipose tissue depletion and abnormal metabolism are among the characteristics of cachexia [103]. While the underlying mechanisms are complex, elevated angiotensin II (Ang II) levels are frequently found in patients with cachexia, and treatment with angiotensin-converting enzyme inhibitor prevents weight loss [104]. Diaphragm muscle biopsies from 22 critically ill patients under mechanical ventilation appeared approximately $25 \%$ smaller in myofibre diameter, and this reduced their contractile force by one-half or more [105]. This protein degradation is mediated by proteolytic pathways, including proteasome and lysosomes [103]. The expression levels of muscle-specific ubiquitin ligases, such as Atrogin-1/MAFbx, MuRF1/ TRIM63, SMART [38], have been accepted as molecular markers of enhanced proteasome-dependent proteolysis in cancer-related cachexia demonstrated in several types of experimental models [106]. Small-molecule inhibiting MuRF1 attenuates skeletal muscle atrophy in cardiac cachexia mouse model [107]. Sestrin1, which is a stressinducible metabolic regulator, preserves muscle mass and force in atrophy condition mouse models, including sarcopenia by blunting FoxO-dependent atrogenes [108]. On the other hand, specific proteasome inhibitors such as bortezomib do not improve the muscle phenotype in cancer-associated cachexia [109]. Others have reported unchanged levels of the UPS pathway in cancer patients $[110,111]$.

Depending on the type of cachexia pathology, there could be different protein degradation pathways involved. Interventional studies using cachexic models are needed to elucidate the role of UPS in the cachexic state. 


\section{Diseases characterised with inflammations Nakajo-Nishimura syndrome}

Proteasome-associated auto-inflammatory syndromes was firstly described in 1939 in patients presenting with recurrent fever beginning in early childhood, accompanied by nodular erythema, rash, and joint contractures [112]. Since then, several syndromes, such as the chronic atypical neutrophilic dermatosis with lipodystrophy and elevated temperatures (CANDLE) syndrome, the Nakajo-Nishimura syndrome (NNS), Joint contractures/ Muscle atrophy/microcytic anaemia/the Panniculitisinduced lipodystrophy (JMP) syndrome, and the Japanese auto-inflammatory syndrome with lipodystrophy, have been used to categorise patients with diseases within the same spectrum, including myositis [113, 114]. As mentioned in Sect. 2, an association between the immunoproteasome and disease has also been reported. Independent studies identified mutations in the immunoproteasome subunit $\beta 5 \mathrm{i}$ gene that result in a sustained inflammatory response $[113,115]$. In response to cytokines, DNA damage, or oxidative stress, cells selectively upregulate the expression of the immunoproteasome. Immunoproteasome accelerates the proteolysis of specific peptide substrates and allows for the facilitated degradation of oxidant damaged proteins, which may accumulate during inflammation. Immunoproteasomemediated proteolysis generates immunogenic epitopes presented by MHC class I molecules [116].

Immunoproteasomes are also critical for skeletal muscle differentiation of myoblasts [117]. The oxidative pathway is dysregulated in $\beta 5 \mathrm{i}$-mutated iPS cell-induced myeloid cells [118]. In a DMD animal model, inhibition of the immunoproteasome was reported to ameliorate cardiomyopathy in mdx mice, reducing the fibrosis [119, 120]. The mechanism of $\beta 5$ i mutations in skeletal muscles remains to be elucidated. These studies are enhancing the importance of analysing about immunoproteasome in the disease mechanism of NNS and muscular dystrophy.

\section{Sporadic inclusion body myositis}

Sporadic inclusion body myositis (sIBM) is the most common form of inflammatory myopathy in individuals aged 50 years or more $[121,122]$. Muscle weakness apparent in the quadriceps, wrist flexors, and finger flexors are the typical clinical findings of sIBM [123]. A muscle biopsy would typically reveal endomysial inflammation, invasion of mononuclear cells into non-necrotic fibres, and rimmed vacuoles. These pathological hallmarks indicate that both inflammation and degeneration contribute to the pathology. As such, sIBM is considered to be caused by protein unfolding/misfolding combined with the formation of inclusion bodies [124]. Inhibition of the elimination of ubiquitinated misfolded/unfolded proteins by proteasome results in cellular accumulation of protein aggregates found in sIBM-affected muscle fibres [14]. Amyloid beta $(A \beta)$ and phosphorylated tau (p-tau) can be found in these aggregates. The effect of $A \beta$ precursor protein (APP) overexpression on proteasome function and the influence of proteasome inhibition on aggresome formation was examined using cultured human muscle fibres [125]. In sIBM-affected muscle biopsies, the $26 \mathrm{~S}$ proteasome subunits have been immune-detected in the $\beta$-tubulin-associated aggresomes, which also contained A $\beta$, p-tau, ubiquitin, and heat shock protein 70 (HSP70). Cultured muscle fibres have been observed to overexpress APP and display diminished proteasomal proteolytic activity, and the addition of a proteasome inhibitor strikingly increases aggresome formation apparently. The formation of inclusion bodies might be followed by abnormal intracellular accumulation of unfolded proteins [126]. As mentioned in Sect. 3.3, the crosstalk between proteasome and autophagy is important. Recently, the role of chaperone-mediated autophagy in the aetiology of sIBM was investigated [127]. Several ubiquitin proteasome genes modulate autophagy. For example, Beclin-1, an essential gene for activation of autophagy, is ubiquitinated by TNF receptor-associated factor 6 (TRAF6) ligase [128]. In addition, TRAF6 has been reported to be involved in muscle atrophy in several cases [128-130].

Dysfunction of UPS, which results in an enhanced autophagic machinery, may be the cause of muscle atrophy in sIBM. Accordingly, in contrast to the protective effect of proteasome inhibitor in muscular dystrophy, proteasome dysfunction may play a role in the accumulation of misfolded, potentially cytotoxic proteins in SIBM myofibres.

\section{Motor neuron disease: indirect cause of muscle atrophy}

Amyotrophic lateral sclerosis (ALS) is a neurodegenerative disorder characterised by the fatal progressive loss of upper and lower motor neurons. In particular, the accumulation of ubiquitinated inclusions containing ALS-causing gene products is a common feature in most familial ALS models; it is also a pathological hallmark of sporadic ALS, indicating that the failure to eliminate detrimental proteins is linked to the pathogenesis of both sporadic and familial ALS. The involvement of UPS dysfunction is strongly suggested by the presence of ubiquitinated inclusions such as skein-like and round hyaline inclusions [131]. The proteasome system is dysregulated in ALS, and the accumulation of superoxide dismutase 1 (SOD1) deposits can be found in the spinal cord of experimental animals and human autopsy cases [132-134]. The continuous expression of mutant SOD1 decreases proteasome activity, and primary cultured embryonic motor neurons are vulnerable to proteasome inhibitor [134]. 
Proteasome subunit Rpt3 conditional knockout mouse in a motor neuron-specific system showed locomotor dysfunction accompanied by progressive motor neuron loss and gliosis [135]. Promoting proteasomal degradation could be a therapeutic strategy for ALS [136].

Mutation causing ALS can also affect the function of UPS. Ubiquilin-2 and p62, two disease-causing genes in ALS, are mainly related to the protein aggregation and degradation pathways; therefore, mutations in the ubiquilin-2 and p62 genes can cause ALS related disorders [137-139]. Recently, exome sequencing of the ALS-FTD family identified the CCNF (encoding cyclin-F) gene as a novel gene associated with ALS [140]. Cyclin-F is the part of Skp1-Cul1-F-box (SCF) E3 ubiquitin-ligase complex that enables proteasome degradation [141]. Cyclin-F binds to valosin-containing protein $(\mathrm{VCP})$, which is also reported to be mutated in ALS [142]. The ATPase activity of VCP promotes cytoplasmic aggregation of TAR DNA-binding protein 43 (TDP-43), which is commonly observed in degenerating neurons in ALS patients [142]. The inhibition of proteasome in motor neuron can be the cause of aggregation of SOD1 or TDP-43, which would be involved in ALS pathomechanism.

Overall, in case of motor neuron disease, UPS has a role to eliminate pathologically aggregated proteins rather than preserving the amounts of functional molecules as is in the case of structural proteins in muscular dystrophy. The inhibition of proteasome in motor neuron can be the cause of aggregation of SOD1 or TDP43, which would be involved in ALS pathomechanism.

\section{Conclusions}

In skeletal muscle, a functional decline due to atrophy is regulated by proteolysis. This nature of the tissue makes the relationship between proteolysis and skeletal muscle complicated. Indeed, the UPS inhibition often leads muscle atrophy and deficit in regeneration, while preserving skeletal muscle in some conditions or diseases. The proteasome inhibitors and ubiquitin ligases are important regulators of the proteolytic system and may be potential therapeutic targets. Further studies are needed to understand how the UPS regulates the dynamics of proteostasis in skeletal muscle, and how its aberrance/dysfunction induces the pathological state. The study considerably enhances our understanding of the UPS regulation/maintenance of skeletal muscle. It will thus be of immense importance to further elucidate the mechanisms behind proteasome-mediated proteolysis, which will ultimately allow us to develop therapeutic intervention for the related diseases.
Acknowledgements

Not applicable.

Authors' contributions

YK, KY and NS wrote, reviewed the manuscript. All authors read and approved the final manuscript.

\section{Funding}

This work was supported by the Grant-in-Aid for Scientific Research KAKENHI (15H05667, 16H05318, 18K07519, 18K17857, and 20H04078). This work was also supported by the Suzuken Memorial Foundation.

\section{Availability of data and materials}

Not applicable.

Ethics approval and consent to participate

Not applicable.

\section{Consent for publication}

Not applicable.

\section{Competing interests}

The authors declare no conflict of interest.

\section{Author details}

${ }_{1}^{1}$ Department of Muscle Development and Regeneration, Institute of Molecular Embryology and Genetics, Kumamoto University, 2-2-1 Honjo, Kumamoto 860-0811, Japan. ${ }^{2}$ Institute for Research On Productive Aging (IRPA), \#201 Kobe hybrid business center, Minami-cho 6-7-6, Minatojima, Kobe 650-0047, Japan. ${ }^{3}$ Department of Neurology, Tohoku University School of Medicine, 1-1 Seiryo-machi, Aoba-ku, Sendai 980-8574, Japan. ${ }^{4}$ Department of Neurology, Shodo-Kai Southern Tohoku General Hospital, 1-2-5, Satonomori, Iwanuma, Miyagi 989-2483, Japan.

Received: 17 June 2020 Accepted: 5 September 2020

Published online: 16 September 2020

References

1. Kwee BJ, Mooney DJ (2017) Biomaterials for skeletal muscle tissue engineering. Curr Opin Biotechnol 47:16-22

2. Rock KL, Gramm C, Rothstein L, Clark K, Stein R, Dick L, Hwang D, Goldberg AL (1994) Inhibitors of the proteasome block the degradation of most cell proteins and the generation of peptides presented on MHC class I molecules. Cell 78:761-771

3. Voges D, Zwickl P, Baumeister W (1999) The 265 proteasome: a molecular machine designed for controlled proteolysis. Annu Rev Biochem 68:1015-1068

4. Glickman MH, Ciechanover A (2002) The ubiquitin-proteasome proteolytic pathway: destruction for the sake of construction. Physiol Rev 82:373-428

5. Zeng BY, Medhurst AD, Jackson M, Rose S, Jenner P (2005) Proteasomal activity in brain differs between species and brain regions and changes with age. Mech Ageing Dev 126:760-766

6. Dasuri K, Nguyen A, Zhang L, Fernandez-Kim OS, Bruce-Keller AJ, Blalock BA, Cabo RD, Keller JN (2009) Comparison of rat liver and brain proteasomes for oxidative stress-induced inactivation: influence of ageing and dietary restriction. Free Radic Res 43:28-36

7. Hayashi T, Goto S (1998) Age-related changes in the $20 \mathrm{~S}$ and $26 \mathrm{~S}$ proteasome activities in the liver of male F344 rats. Mech Ageing Dev 102:55-66

8. Bulteau AL, Szweda LI, Friguet B (2002) Age-dependent declines in proteasome activity in the heart. Arch Biochem Biophys 397:298-304

9. Ferrington DA, Husom AD, Thompson LV (2005) Altered proteasome structure, function, and oxidation in aged muscle. FASEB J 19:644-646

10. Chen Q, Thorpe J, Dohmen JR, Li F, Keller JN (2006) Ump1 extends yeast lifespan and enhances viability during oxidative stress: central role for the proteasome? Free Radic Biol Med 40:120-126 
11. Vilchez D, Morantte I, Liu Z, Douglas PM, Merkwirth C, Rodrigues AP, Manning G, Dillin A (2012) RPN-6 determines C. elegans longevity under proteotoxic stress conditions. Nature 489:263-268

12. Tomaru U, Takahashi S, Ishizu A, Miyatake Y, Gohda A, Suzuki S, Ono A, Ohara J, Baba T, Murata S, Tanaka K, Kasahara M (2012) Decreased proteasomal activity causes age-related phenotypes and promotes the development of metabolic abnormalities. Am J Pathol 180:963-972

13. Tonoki A, Kuranaga E, Tomioka T, Hamazaki J, Murata S, Tanaka K, Miura M (2009) Genetic evidence linking age-dependent attenuation of the $26 \mathrm{~S}$ proteasome with the aging process. Mol Cell Biol 29:1095-1106

14. Kitajima Y, Tashiro Y, Suzuki N, Warita H, Kato M, Tateyama M, Ando R, Izumi R, Yamazaki M, Abe M, Sakimura K, Ito H, Urushitani M, Nagatom R, Takahashi R, Aoki M (2014) Proteasome dysfunction induces muscle growth defects and protein aggregation. J Cell Sci 127:5204-5217

15. Kitajima Y, Suzuki N, Yoshioka K, Izumi R, Tateyama M, Tashiro Y, Takahashi R, Aoki M, Ono Y (2020) Inducible Rpt3, a proteasome component, knockout in adult skeletal muscle results in muscle atrophy. Front Cell Dev Biol. https://doi.org/10.3389/fcell.2020.00859

16. Sandri M, Coletto L, Grumati P, Bonaldo P (2013) Misregulation of autophagy and protein degradation systems in myopathies and muscular dystrophies. J Cell Sci 126:5325-5333

17. Baumeister W, Walz J, Zuhl F, Seemuller E (1998) The proteasome: paradigm of a self-compartmentalizing protease. Cell 92:367-380

18. Tanaka K (2009) The proteasome: overview of structure and functions. Proc Jpn Acad Ser B Phys Biol Sci 85:12-36

19. Dick TP, Nussbaum AK, Deeg M, Heinemeyer W, Groll M, Schirle M, Keilholz W, Stevanovic S, Wolf DH, Huber R, Rammensee HG, Schild $H$ (1998) Contribution of proteasomal beta-subunits to the cleavage of peptide substrates analyzed with yeast mutants. J Biol Chem 273:25637-25646

20. Kisselev AF, Akopian TN, Castillo V, Goldberg AL (1999) Proteasome active sites allosterically regulate each other, suggesting a cyclical bitechew mechanism for protein breakdown. Mol Cell 4:395-402

21. Deveraux Q, Ustrell V, Pickart C, Rechsteiner M (1994) A 26 S protease subunit that binds ubiquitin conjugates. J Biol Chem 269:7059-7061

22. van Nocker S, Sadis S, Rubin DM, Glickman M, Fu H, Coux O, Wefes I, Finley D, Vierstra RD (1996) The multiubiquitin-chain-binding protein Mcb1 is a component of the $26 \mathrm{~S}$ proteasome in Saccharomyces cerevisiae and plays a nonessential, substrate-specific role in protein turnover. Mol Cell Biol 16:6020-6028

23. Sakao Y, Kawai T, Takeuchi O, Copeland NG, Gilbert DJ, Jenkins NA, Takeda K, Akira S (2000) Mouse proteasomal ATPases Psmc3 and Psmc4: genomic organization and gene targeting. Genomics 67:1-7

24. Rosenzweig R, Bronner V, Zhang D, Fushman D, Glickman MH (2012) Rpn1 and Rpn2 coordinate ubiquitin processing factors at proteasome. J Biol Chem 287:14659-14671

25. Schreiner P, Chen X, Husnjak K, Randles L, Zhang N, Elsasser S, Finley D, Dikic I, Walters KJ, Groll M (2008) Ubiquitin docking at the proteasome through a novel pleckstrin-homology domain interaction. Nature 453:548-552

26. Hamazaki J, lemura S, Natsume T, Yashiroda H, Tanaka K, Murata S (2006) A novel proteasome interacting protein recruits the deubiquitinating enzyme UCH37 to 265 proteasomes. EMBO J 25:4524-4536

27. Yao T, Song L, Xu W, DeMartino GN, Florens L, Swanson SK, Washburn MP, Conaway RC, Conaway JW, Cohen RE (2006) Proteasome recruitment and activation of the Uch37 deubiquitinating enzyme by Adrm 1 . Nat Cell Biol 8:994-1002

28. Petroski MD, Deshaies RJ (2005) Function and regulation of cullin-RING ubiquitin ligases. Nat Rev Mol Cell Biol 6:9-20

29. Cai D, Frantz JD, Tawa NE Jr, Melendez PA, Oh BC, Lidov HG, Hasselgren PO, Frontera WR, Lee J, Glass DJ, Shoelson SE (2004) IKKbeta/NF-kappaB activation causes severe muscle wasting in mice. Cell 119:285-298

30. Sandri M, Sandri C, Gilbert A, Skurk C, Calabria E, Picard A, Walsh K, Schiaffino S, Lecker SH, Goldberg AL (2004) Foxo transcription factors induce the atrophy-related ubiquitin ligase atrogin-1 and cause skeletal muscle atrophy. Cell 117:399-412

31. Stitt TN, Drujan D, Clarke BA, Panaro F, Timofeyva Y, Kline WO, Gonzalez M, Yancopoulos GD, Glass DJ (2004) The IGF-1/PI3K/Akt pathway prevents expression of muscle atrophy-induced ubiquitin ligases by inhibiting FOXO transcription factors. Mol Cell 14:395-403
32. Bodine SC, Latres E, Baumhueter S, Lai VK, Nunez L, Clarke BA, Poueymirou WT, Panaro FJ, Na E, Dharmarajan K, Pan ZQ, Valenzuela DM, DeChiara TM, Stitt TN, Yancopoulos GD, Glass DJ (2001) Identification of ubiquitin ligases required for skeletal muscle atrophy. Science 294:1704-1708

33. Gomes MD, Lecker SH, Jagoe RT, Navon A, Goldberg AL (2001) Atrogin-1, a muscle-specific F-box protein highly expressed during muscle atrophy. Proc Natl Acad Sci USA 98:14440-14445

34. Foletta VC, White $L$, Larsen $A E$, Leger $B$, Russell AP (2011) The role and regulation of MAFbx/atrogin-1 and MURF1 in skeletal muscle atrophy. Pflugers Arch 461:325-335

35. Nikawa T, Ishidoh K, Hirasaka K, Ishihara I, Ikemoto M, Kano M, Kominami E, Nonaka I, Ogawa T, Adams GR, Baldwin KM, Yasui N, Kishi K, Takeda S (2004) Skeletal muscle gene expression in space-flown rats. FASEB J 18:522-524

36. Nakao R, Hirasaka K, Goto J, Ishidoh K, Yamada C, Ohno A, Okumura Y, Nonaka I, Yasutomo K, Baldwin KM, Kominami E, Higashibata A, Nagano K, Tanaka K, Yasui N, Mills EM, Takeda S, Nikawa T (2009) Ubiquitin ligase $\mathrm{Cbl}-\mathrm{b}$ is a negative regulator for insulin-like growth factor 1 signaling during muscle atrophy caused by unloading. Mol Cell Biol 29:4798-4811

37. Sartori R, Schirwis E, Blaauw B, Bortolanza S, Zhao J, Enzo E, Stantzou A, Mouisel E, Toniolo L, Ferry A, Stricker S, Goldberg AL, Dupont S, Piccolo S, Amthor H, Sandri M (2013) BMP signaling controls muscle mass. Nat Genet 45:1309-1318

38. Milan G, Romanello V, Pescatore F, Armani A, Paik JH, Frasson L, Seydel A, Zhao J, Abraham R, Goldberg AL, Blaauw B, DePinho RA, Sandri M (2015) Regulation of autophagy and the ubiquitin-proteasome system by the FoxO transcriptional network during muscle atrophy. Nat Commun 6:6670

39. Hughes DC, Baehr LM, Driscoll JR, Lynch SA, Waddell DS, Bodine SC (2020) Identification and characterization of Fbxl22, a novel skeletal muscle atrophy-promoting E3 ubiquitin ligase. bioRxiv: 2020.2004.2024.059659

40. Goldberg AL (2003) Protein degradation and protection against misfolded or damaged proteins. Nature 426:895-899

41. Attaix D, Aurousseau E, Combaret L, Kee A, Larbaud D, Ralliere C, Souweine B, Taillandier D, Tilignac T (1998) Ubiquitin-proteasomedependent proteolysis in skeletal muscle. Reprod Nutr Dev 38:153-165

42. Hasselgren PO, Wray C, Mammen J (2002) Molecular regulation of muscle cachexia: it may be more than the proteasome. Biochem Biophys Res Commun 290:1-10

43. Li JB, Goldberg AL (1976) Effects of food deprivation on protein synthesis and degradation in rat skeletal muscles. Am J Physiol 231:441-448

44. Matsakas A, Patel K (2009) Skeletal muscle fibre plasticity in response to selected environmental and physiological stimuli. Histol Histopathol 24:611-629

45. Sandri M, Lin J, Handschin C, Yang W, Arany ZP, Lecker SH, Goldberg AL, Spiegelman BM (2006) PGC-1alpha protects skeletal muscle from atrophy by suppressing FoxO3 action and atrophy-specific gene transcription. Proc Natl Acad Sci USA 103:16260-16265

46. Klionsky DJ (2008) Autophagy revisited: a conversation with Christian de Duve. Autophagy 4:740-743

47. Mizushima N, Yamamoto A, Matsui M, Yoshimori T, Ohsumi Y (2004) In vivo analysis of autophagy in response to nutrient starvation using transgenic mice expressing a fluorescent autophagosome marker. Mol Biol Cell 15:1101-1111

48. Kuma A, Hatano M, Matsui M, Yamamoto A, Nakaya H, Yoshimori T, Ohsumi Y, Tokuhisa T, Mizushima N (2004) The role of autophagy during the early neonatal starvation period. Nature 432:1032-1036

49. Saitoh T, Fujita N, Jang MH, Uematsu S, Yang BG, Satoh T, Omori H, Noda T, Yamamoto N, Komatsu M, Tanaka K, Kawai T, Tsujimura T, Takeuchi O, Yoshimori T, Akira S (2008) Loss of the autophagy protein Atg16L1 enhances endotoxin-induced IL-1 beta production. Nature 456:264-268

50. Singh R, Kaushik S, Wang Y, Xiang Y, Novak I, Komatsu M, Tanaka K, Cuervo AM, Czaja MJ (2009) Autophagy regulates lipid metabolism. Nature 458:1131-1135

51. Wang X, Blagden C, Fan J, Nowak SJ, Taniuchi I, Littman DR, Burden SJ (2005) Runx1 prevents wasting, myofibrillar disorganization, and autophagy of skeletal muscle. Genes Dev 19:1715-1722 
52. Mammucari C, Milan G, Romanello V, Masiero E, Rudolf R, Del Piccolo P, Burden SJ, Di Lisi R, Sandri C, Zhao J, Goldberg AL, Schiaffino S, Sandri M (2007) FoxO3 controls autophagy in skeletal muscle in vivo. Cell Metab 6:458-471

53. Zhao J, Brault JJ, Schild A, Cao P, Sandri M, Schiaffino S, Lecker SH, Goldberg AL (2007) FoxO3 coordinately activates protein degradation by the autophagic/lysosomal and proteasomal pathways in atrophying muscle cells. Cell Metab 6:472-483

54. Masiero E, Agatea L, Mammucari C, Blaauw B, Loro E, Komatsu M, Metzger D, Reggiani C, Schiaffino S, Sandri M (2009) Autophagy is required to maintain muscle mass. Cell Metab 10:507-515

55. Castets $\mathrm{P}$, Lin $\mathrm{S}$, Rion N, Di Fulvio S, Romanino K, Guridi M, Frank S, Tintignac LA, Sinnreich M, Ruegg MA (2013) Sustained activation of mTORC1 in skeletal muscle inhibits constitutive and starvation-induced autophagy and causes a severe, late-onset myopathy. Cell Metab 17:731-744

56. Ciechanover A, Finley D, Varshavsky A (1984) Ubiquitin dependence of selective protein degradation demonstrated in the mammalian cell cycle mutant ts85. Cell 37:57-66

57. Pickart CM (2004) Back to the future with ubiquitin. Cell 116:181-190

58. Pankiv S, Clausen TH, Lamark T, Brech A, Bruun JA, Outzen H, Overvatn A, Bjorkoy G, Johansen T (2007) p62/SQSTM1 binds directly to Atg8/ LC3 to facilitate degradation of ubiquitinated protein aggregates by autophagy. J Biol Chem 282:24131-24145

59. Iwata A, Riley BE, Johnston JA, Kopito RR (2005) HDAC6 and microtubules are required for autophagic degradation of aggregated huntingtin. J Biol Chem 280:40282-40292

60. Pandey UB, Nie Z, Batlevi Y, McCray BA, Ritson GP, Nedelsky NB, Schwartz SL, DiProspero NA, Knight MA, Schuldiner O, Padmanabhan R, Hild M, Berry DL, Garza D, Hubbert CC, Yao TP, Baehrecke EH, Taylor JP (2007) HDAC6 rescues neurodegeneration and provides an essential link between autophagy and the UPS. Nature 447:859-863

61. Murphy MM, Lawson JA, Mathew SJ, Hutcheson DA, Kardon G (2011) Satellite cells, connective tissue fibroblasts and their interactions are crucial for muscle regeneration. Development 138:3625-3637

62. Kitajima Y, Suzuki N, Nunomiya A, Osana S, Yoshioka K, Tashiro Y, Takahashi R, Ono Y, Aoki M, Nagatomi R (2018) The ubiquitin-proteasome system is indispensable for the maintenance of muscle stem cells. Stem Cell Reports 11:1523-1538

63. Duguez S, Bihan MC, Gouttefangeas D, Feasson L, Freyssenet D (2003) Myogenic and nonmyogenic cells differentially express proteinases, Hsc/Hsp70, and BAG-1 during skeletal muscle regeneration. Am J Physiol Endocrinol Metab 285:E206-215

64. Abu Hatoum O, Gross-Mesilaty S, Breitschopf K, Hoffman A, Gonen H, Ciechanover A, Bengal E (1998) Degradation of myogenic transcription factor MyoD by the ubiquitin pathway in vivo and in vitro: regulation by specific DNA binding. Mol Cell Biol 18:5670-5677

65. Gardrat F, Montel V, Raymond J, Azanza JL (1997) Proteasome and myogenesis. Mol Biol Rep 24:77-81

66. Kim SS, Rhee S, Lee KH, Kim JH, Kim HS, Kang MS, Chung CH (1998) Inhibitors of the proteasome block the myogenic differentiation of rat L6 myoblasts. FEBS Lett 433:47-50

67. Halevy O, Novitch BG, Spicer DB, Skapek SX, Rhee J, Hannon GJ, Beach D, Lassar AB (1995) Correlation of terminal cell cycle arrest of skeletal muscle with induction of p21 by MyoD. Science 267:1018-1021

68. Porrello A, Cerone MA, Coen S, Gurtner A, Fontemaggi G, Cimino L, Piaggio G, Sacchi A, Soddu S (2000) p53 regulates myogenesis by triggering the differentiation activity of pRb. J Cell Biol 151:1295-1304

69. Soddu S, Blandino G, Scardigli R, Coen S, Marchetti A, Rizzo MG, Bossi G, Cimino L, Crescenzi M, Sacchi A (1996) Interference with p53 protein inhibits hematopoietic and muscle differentiation. J Cell Biol 134:193-204

70. Tamir Y, Bengal E (1998) p53 protein is activated during muscle differentiation and participates with MyoD in the transcription of muscle creatine kinase gene. Oncogene 17:347-356

71. Weintraub H, Hauschka S, Tapscott SJ (1991) The MCK enhancer contains a p53 responsive element. Proc Natl Acad Sci USA 88:4570-4571

72. Flamini V, Ghadiali RS, Antczak P, Rothwell A, Turnbull JE, Pisconti A (2018) The satellite cell niche regulates the balance between myoblast differentiation and self-renewal via p53. Stem Cell Rep 10:970-983
73. Verhaart IEC, Aartsma-Rus A (2019) Therapeutic developments for Duchenne muscular dystrophy. Nat Rev Neurol 15:373-386

74. Talsness DM, Belanto JJ, Ervasti JM (2015) Disease-proportional proteasomal degradation of missense dystrophins. Proc Natl Acad Sci USA 112:12414-12419

75. Bonuccelli G, Sotgia F, Schubert W, Park DS, Frank PG, Woodman SE, Insabato L, Cammer M, Minetti C, Lisanti MP (2003) Proteasome inhibitor (MG-132) treatment of $\mathrm{mdx}$ mice rescues the expression and membrane localization of dystrophin and dystrophin-associated proteins. Am J Pathol 163:1663-1675

76. Gazzerro E, Assereto S, Bonetto A, Sotgia F, Scarfi S, Pistorio A, Bonuccelli G, Cilli M, Bruno C, Zara F, Lisanti MP, Minetti C (2010) Therapeutic potential of proteasome inhibition in Duchenne and Becker muscular dystrophies. Am J Pathol 176:1863-1877

77. Araujo KP, Bonuccelli G, Duarte CN, Gaiad TP, Moreira DF, Feder D, Belizario JE, Miglino MA, Lisanti MP, Ambrosio CE (2013) Bortezomib (PS-341) treatment decreases inflammation and partially rescues the expression of the dystrophin-glycoprotein complex in GRMD dogs. PLOS ONE 8:e61367

78. Korner Z, Fontes-Oliveira CC, Holmberg J, Carmignac V, Durbeej M (2014) Bortezomib partially improves laminin alpha2 chain-deficient muscular dystrophy. Am J Pathol 184:1518-1528

79. Korner Z, Durbeej M (2016) Bortezomib does not reduce muscular dystrophy in the dy2 J/dy2J mouse model of laminin alpha2 chaindeficient muscular dystrophy. PLoS ONE 11:e0146471

80. Azakir BA, Di Fulvio S, Kinter J, Sinnreich M (2017) Proteasomal inhibition restores biological function of mis-sense mutated dysferlin in patient-derived muscle cells. J Biol Chem 292:12542

81. Olive M, Abdul-Hussein S, Oldfors A, Gonzalez-Costello J, van der Ven PF, Furst DO, Gonzalez L, Moreno D, Torrejon-Escribano B, Alio J, Pou A, Ferrer I, Tajsharghi H (2015) New cardiac and skeletal protein aggregate myopathy associated with combined MuRF1 and MuRF3 mutations. Hum Mol Genet 24:3638-3650

82. Hnia K, Clausen T, Moog-Lutz C (2019) Shaping striated muscles with ubiquitin proteasome system in health and disease. Trends Mol Med 25:760-774

83. McElhinny AS, Kakinuma K, Sorimachi H, Labeit S, Gregorio CC (2002) Muscle-specific RING finger-1 interacts with titin to regulate sarcomeric $\mathrm{M}$-line and thick filament structure and may have nuclear functions via its interaction with glucocorticoid modulatory element binding protein-1. J Cell Biol 157:125-136

84. Cohen S, Brault JJ, Gygi SP, Glass DJ, Valenzuela DM, Gartner C, Latres E, Goldberg AL (2009) During muscle atrophy, thick, but not thin, filament components are degraded by MuRF1-dependent ubiquitylation. J Cell Biol 185:1083-1095

85. Kedar V, McDonough H, Arya R, Li HH, Rockman HA, Patterson C (2004) Muscle-specific RING finger 1 is a bona fide ubiquitin ligase that degrades cardiac troponin I. Proc Natl Acad Sci USA 101:18135-18140

86. Moreira ES, Wiltshire TJ, Faulkner G, Nilforoushan A, Vainzof M, Suzuki OT, Valle G, Reeves R, Zatz M, Passos-Bueno MR, Jenne DE (2000) Limbgirdle muscular dystrophy type $2 \mathrm{G}$ is caused by mutations in the gene encoding the sarcomeric protein telethonin. Nat Genet 24:163-166

87. Fielitz J, Kim MS, Shelton JM, Latif S, Spencer JA, Glass DJ, Richardson JA, Bassel-Duby R, Olson EN (2007) Myosin accumulation and striated muscle myopathy result from the loss of muscle RING finger 1 and 3. J Clin Invest 117:2486-2495

88. Cohen S, Zhai B, Gygi SP, Goldberg AL (2012) Ubiquitylation by Trim32 causes coupled loss of desmin, Z-bands, and thin filaments in muscle atrophy. J Cell Biol 198:575-589

89. Nagpal P, Plant PJ, Correa J, Bain A, Takeda M, Kawabe H, Rotin D, Bain JR, Batt JA (2012) The ubiquitin ligase Nedd4-1 participates in denervationinduced skeletal muscle atrophy in mice. PLoS ONE 7:e46427

90. Screen M, Jonson PH, Raheem O, Palmio J, Laaksonen R, Lehtimaki T, Sirito M, Krahe R, Hackman P, Udd B (2014) Abnormal splicing of NEDD4 in myotonic dystrophy type 2: possible link to statin adverse reactions. Am J Pathol 184:2322-2332

91. Li HH, Kedar V, Zhang C, McDonough H, Arya R, Wang DZ, Patterson C (2004) Atrogin-1/muscle atrophy F-box inhibits calcineurin-dependent cardiac hypertrophy by participating in an SCF ubiquitin ligase complex. J Clin Invest 114:1058-1071 
92. Mearini G, Gedicke C, Schlossarek S, Witt CC, Kramer E, Cao P, Gomes MD, Lecker SH, Labeit S, Willis MS, Eschenhagen T, Carrier L (2010) Atrogin-1 and MuRF1 regulate cardiac MyBP-C levels via different mechanisms. Cardiovasc Res 85:357-366

93. Bilodeau PA, Coyne ES, Wing SS (2016) The ubiquitin proteasome system in atrophying skeletal muscle: roles and regulation. Am J Physiol Cell Physiol 311:C392-403

94. Gupta VA, Beggs AH (2014) Kelch proteins: emerging roles in skeletal muscle development and diseases. Skelet Muscle 4:11

95. Garg A, O'Rourke J, Long C, Doering J, Ravenscroft G, Bezprozvannaya S, Nelson BR, Beetz N, Li L, Chen S, Laing NG, Grange RW, Bassel-Duby R, Olson EN (2014) KLHL40 deficiency destabilizes thin filament proteins and promotes nemaline myopathy. J Clin Invest 124:3529-3539

96. Sambuughin N, Yau KS, Olive M, Duff RM, Bayarsaikhan M, Lu S, Gonzalez-Mera L, Sivadorai P, Nowak KJ, Ravenscroft G, Mastaglia FL, North KN, Ilkovski B, Kremer H, Lammens M, van Engelen BG, Fabian V, Lamont P, Davis MR, Laing NG, Goldfarb LG (2010) Dominant mutations in KBTBD13, a member of the BTB/Kelch family, cause nemaline myopathy with cores. Am J Hum Genet 87:842-847

97. Ramirez-Martinez A, Cenik BK, Bezprozvannaya S, Chen B, Bassel-Duby R, Liu N, Olson EN (2017) KLHL41 stabilizes skeletal muscle sarcomeres by nonproteolytic ubiquitination. Elife 6:12

98. Gupta VA, Ravenscroft G, Shaheen R, Todd EJ, Swanson LC, Shiina M, Ogata K, Hsu C, Clarke NF, Darras BT, Farrar MA, Hashem A, Manton ND, Muntoni F, North KN, Sandaradura SA, Nishino I, Hayashi YK, Sewry CA, Thompson EM, Yau KS, Brownstein CA, Yu TW, Allcock RJ, Davis MR, Wallgren-Pettersson C, Matsumoto N, Alkuraya FS, Laing NG, Beggs AH (2013) Identification of KLHL41 mutations implicates BTB-Kelch-mediated ubiquitination as an alternate pathway to myofibrillar disruption in nemaline myopathy. Am J Hum Genet 93:1108-1117

99. Jirka C, Pak JH, Grosgogeat CA, Marchetii MM, Gupta VA (2019) Dysregulation of NRAP degradation by KLHL41 contributes to pathophysiology in Nemaline Myopathy. Hum Mol Genet 28(15):2549-2560

100. Liu CC, Lin YC, Chen YH, Chen CM, Pang LY, Chen HA, Wu PR, Lin MY, Jiang ST, Tsai TF, Chen RH (2016) Cul3-KLHL20 ubiquitin ligase governs the turnover of ULK1 and VPS34 complexes to control autophagy termination. Mol Cell 61:84-97

101. Yuan WC, Lee YR, Lin SY, Chang LY, Tan YP, Hung CC, Kuo JC, Liu CH, Lin MY, Xu M, Chen ZJ, Chen RH (2014) K33-linked polyubiquitination of Coronin 7 by Cul3-KLHL20 ubiquitin E3 ligase regulates protein trafficking. Mol Cell 54:586-600

102. Yoshida T, Delafontaine $P(2015)$ Mechanisms of cachexia in chronic disease states. Am J Med Sci 350:250-256

103. Penna F, Ballaro R, Beltra M, De Lucia S, Garcia Castillo L, Costelli P (2019) The skeletal muscle as an active player against cancer cachexia. Front Physiol 10:41

104. Anker SD, Negassa A, Coats AJ, Afzal R, Poole-Wilson PA, Cohn JN, Yusuf $S$ (2003) Prognostic importance of weight loss in chronic heart failure and the effect of treatment with angiotensin-converting-enzyme inhibitors: an observational study. Lancet 361:1077-1083

105. Hooijman PE, Beishuizen A, Witt CC, de Waard MC, Girbes AR, Spoelstrade Man AM, Niessen HW, Manders E, van Hees HW, van den Brom CE, Silderhuis V, Lawlor MW, Labeit S, Stienen GJ, Hartemink KJ, Paul MA, Heunks LM, Ottenheijm CA (2015) Diaphragm muscle fiber weakness and ubiquitin-proteasome activation in critically ill patients. Am J Respir Crit Care Med 191:1126-1138

106. Argiles JM, Busquets S, Stemmler B, Lopez-Soriano FJ (2014) Cancer cachexia: understanding the molecular basis. Nat Rev Cancer 14:754-762

107. Adams V, Bowen TS, Werner S, Barthel P, Amberger C, Konzer A, Graumann J, Sehr P, Lewis J, Provaznik J, Benes V, Buttner P, Gasch A, Mangner N, Witt CC, Labeit D, Linke A, Labeit S (2019) Small-moleculemediated chemical knock-down of MuRF1/MuRF2 and attenuation of diaphragm dysfunction in chronic heart failure. J Cachexia Sarcopenia Muscle 10:1102-1115

108. Segales J, Perdiguero E, Serrano AL, Sousa-Victor P, Ortet L, Jardi M, Budanov AV, Garcia-Prat L, Sandri M, Thomson DM, Karin M, Hee Lee J, Munoz-Canoves P (2020) Sestrin prevents atrophy of disused and aging muscles by integrating anabolic and catabolic signals. Nat Commun 11:189
109. Penna F, Busquets S, Argiles JM (2016) Experimental cancer cachexia: evolving strategies for getting closer to the human scenario. Semin Cell Dev Biol 54:20-27

110. Tardif N, Klaude M, Lundell L, Thorell A, Rooyackers O (2013) Autophagic-lysosomal pathway is the main proteolytic system modified in the skeletal muscle of esophageal cancer patients. Am J Clin Nutr 98:1485-1492

111. Op den Kamp CM, Langen RC, Minnaard R, Kelders MC, Snepvangers FJ, Hesselink MK, Dingemans AC, Schols AM (2012) Pre-cachexia in patients with stages I-III non-small cell lung cancer: systemic inflammation and functional impairment without activation of skeletal muscle ubiquitin proteasome system. Lung Cancer 76:112-117

112. McDermott A, Jacks J, Kessler M, Emanuel PD, Gao L (2015) Proteasomeassociated autoinflammatory syndromes: advances in pathogeneses, clinical presentations, diagnosis, and management. Int J Dermatol 54:121-129

113. Agarwal AK, Xing C, DeMartino GN, Mizrachi D, Hernandez MD, Sousa AB, Martinez de Villarreal L, dos Santos HG, Garg A (2010) PSMB8 encoding the beta5i proteasome subunit is mutated in joint contractures, muscle atrophy, microcytic anemia, and panniculitis-induced lipodystrophy syndrome. Am J Hum Genet 87:866-872

114. Brehm A, Liu Y, Sheikh A, Marrero B, Omoyinmi E, Zhou Q, Montealegre G, Biancotto A, Reinhardt A, Almeida de Jesus A, Pelletier M, Tsai WL, Remmers EF, Kardava L, Hill S, Kim H, Lachmann HJ, Megarbane A, Chae JJ, Brady J, Castillo RD, Brown D, Casano AV, Gao L, Chapelle D, Huang Y, Stone D, Chen Y, Sotzny F, Lee CC, Kastner DL, Torrelo A, Zlotogorski A, Moir S, Gadina M, McCoy P, Wesley R, Rother Kl, Hildebrand PW, Brogan P, Kruger E, Aksentijevich I, Goldbach-Mansky R (2015) Additive loss-offunction proteasome subunit mutations in CANDLE/PRAAS patients promote type I IFN production. J Clin Invest 125:4196-4211

115. Arima K, Kinoshita A, Mishima H, Kanazawa N, Kaneko T, Mizushima T, Ichinose K, Nakamura H, Tsujino A, Kawakami A, Matsunaka M, Kasagi S, Kawano S, Kumagai S, Ohmura K, Mimori T, Hirano M, Ueno S, Tanaka K, Tanaka M, Toyoshima I, Sugino H, Yamakawa A, Tanaka K, Niikawa N, Furukawa F, Murata S, Equchi K, Ida H, Yoshiura K (2011) Proteasome assembly defect due to a proteasome subunit beta type 8 (PSMB8) mutation causes the autoinflammatory disorder, Nakajo-Nishimura syndrome. Proc Natl Acad Sci USA 108:14914-14919

116. Ohmura K (2019) Nakajo-Nishimura syndrome and related proteasomeassociated autoinflammatory syndromes. J Inflamm Res 12:259-265

117. Cui Z, Hwang SM, Gomes AV (2014) Identification of the immunoproteasome as a novel regulator of skeletal muscle differentiation. Mol Cell Biol 34:96-109

118. Honda-Ozaki F, Terashima M, Niwa A, Saiki N, Kawasaki Y, Ito H, Hotta A, Nagahashi A, Igura K, Asaka I, Li HL, Yanagimachi M, Furukawa F, Kanazawa N, Nakahata T, Saito MK (2018) Pluripotent stem cell model of Nakajo-Nishimura syndrome untangles proinflammatory pathways mediated by oxidative stress. Stem Cell Rep 10:1835-1850

119. Farini A, Gowran A, Bella P, Sitzia C, Scopece A, Castiglioni E, Rovina D, Nigro P, Villa C, Fortunato F, Comi GP, Milano G, Pompilio G, Torrente Y (2019) Fibrosis rescue improves cardiac function in Dystrophin-deficient mice and Duchenne patient-specific cardiomyocytes by immunoproteasome modulation. Am J Pathol 189:339-353

120. Farini A, Sitzia C, Cassani B, Cassinelli L, Rigoni R, Colleoni F, Fusco N, Gatti S, Bella P, Villa C, Napolitano F, Maiavacca R, Bosari S, Villa A, Torrente $Y$ (2016) Therapeutic potential of immunoproteasome inhibition in duchenne muscular dystrophy. Mol Ther 24:1898-1912

121. Greenberg SA (2019) Inclusion body myositis: clinical features and pathogenesis. Nat Rev Rheumatol 15:257-272

122. Selva-O'Callaghan A, Pinal-Fernandez I, Trallero-Araguas E, Milisenda JC, Grau-Junyent JM, Mammen AL (2018) Classification and management of adult inflammatory myopathies. Lancet Neurol 17:816-828

123. Needham M, Mastaglia FL (2016) Sporadic inclusion body myositis: a review of recent clinical advances and current approaches to diagnosis and treatment. Clin Neurophysiol 127:1764-1773

124. Askanas V, Engel WK, Nogalska A (2009) Inclusion body myositis: a degenerative muscle disease associated with intra-muscle fiber multiprotein aggregates, proteasome inhibition, endoplasmic reticulum stress and decreased lysosomal degradation. Brain Pathol 19:493-506

125. Fratta P, Engel WK, McFerrin J, Davies KJ, Lin SW, Askanas V (2005) Proteasome inhibition and aggresome formation in sporadic 
inclusion-body myositis and in amyloid-beta precursor protein-overexpressing cultured human muscle fibers. Am J Pathol 167:517-526

126. Askanas V, Engel WK (2006) Inclusion-body myositis: a myodegenerative conformational disorder associated with Abeta, protein misfolding, and proteasome inhibition. Neurology 66:S39-48

127. Cacciottolo M, Nogalska A, D’Agostino C, Engel WK, Askanas V (2013) Chaperone-mediated autophagy components are upregulated in sporadic inclusion-body myositis muscle fibres. Neuropathol Appl Neurobiol 39:750-761

128. Paul PK, Gupta SK, Bhatnagar S, Panguluri SK, Darnay BG, Choi Y, Kumar A (2010) Targeted ablation of TRAF6 inhibits skeletal muscle wasting in mice. J Cell Biol 191:1395-1411

129. Paul PK, Bhatnagar S, Mishra V, Srivastava S, Darnay BG, Choi Y, Kumar A (2012) The E3 ubiquitin ligase TRAF6 intercedes in starvation-induced skeletal muscle atrophy through multiple mechanisms. Mol Cell Biol 32:1248-1259

130. Sun H, Gong Y, Qiu J, Chen Y, Ding F, Zhao Q (2014) TRAF6 inhibition rescues dexamethasone-induced muscle atrophy. Int J Mol Sci 15:11126-11141

131. Maurel C, Dangoumau A, Marouillat S, Brulard C, Chami A Hergesheimer R, Corcia P, Blasco H, Andres CR, Vourc'h P (2018) Causative genes in amyotrophic lateral sclerosis and protein degradation pathways: a link to neurodegeneration. Mol Neurobiol 55:6480-6499

132. Cheroni C, Peviani M, Cascio P, Debiasi S, Monti C, Bendotti C (2005) Accumulation of human SOD1 and ubiquitinated deposits in the spinal cord of SOD1G93A mice during motor neuron disease progression correlates with a decrease of proteasome. Neurobiol Dis 18:509-522

133. Kato S, Saeki Y, Aoki M, Nagai M, Ishigaki A, Itoyama Y, Kato M, Asayama K, Awaya A, Hirano A, Ohama E (2004) Histological evidence of redox system breakdown caused by superoxide dismutase 1 (SOD1) aggregation is common to SOD1-mutated motor neurons in humans and animal models. Acta Neuropathol 107:149-158

134. Urushitani M, Kurisu J, Tsukita K, Takahashi R (2002) Proteasomal inhibition by misfolded mutant superoxide dismutase 1 induces selective motor neuron death in familial amyotrophic lateral sclerosis. J Neurochem 83:1030-1042

135. Tashiro $Y$, Urushitani M, Inoue H, Koike M, Uchiyama Y, Komatsu M, Tanaka K, Yamazaki M, Abe M, Misawa H, Sakimura K, Ito H, Takahashi R (2012) Motor neuron-specific disruption of proteasomes, but not autophagy, replicates amyotrophic lateral sclerosis. J Biol Chem 287:42984-42994

136. Urushitani M, Kurisu J, Tateno M, Hatakeyama S, Nakayama K, Kato S, Takahashi R (2004) CHIP promotes proteasomal degradation of familial
ALS-linked mutant SOD1 by ubiquitinating Hsp/Hsc70. J Neurochem 90:231-244

137. Deng HX, Chen W, Hong ST, Boycott KM, Gorrie GH, Siddique N, Yang Y, Fecto F, Shi Y, Zhai H, Jiang H, Hirano M, Rampersaud E, Jansen GH, Donkervoort S, Bigio EH, Brooks BR, Ajroud K, Sufit RL, Haines JL, Mugnaini E, Pericak-Vance MA, Siddique T (2011) Mutations in UBQLN2 cause dominant X-linked juvenile and adult-onset ALS and ALS/ dementia. Nature 477:211-215

138. Fecto F, Yan J, Vemula SP, Liu E, Yang Y, Chen W, Zheng JG, Shi Y, Siddique N, Arrat H, Donkervoort S, Ajroud-Driss S, Sufit RL, Heller SL, Deng HX, Siddique T (2011) SQSTM1 mutations in familial and sporadic amyotrophic lateral sclerosis. Arch Neurol 68:1440-1446

139. Le Ber I, Camuzat A, Guerreiro R, Bouya-Ahmed K, Bras J, Nicolas G, Gabelle A, Didic M, De Septenville A, Millecamps S, Lenglet T, Latouche M, Kabashi E, Campion D, Hannequin D, Hardy J, Brice A, French C (2013) SQSTM1 mutations in French patients with frontotemporal dementia or frontotemporal dementia with amyotrophic lateral sclerosis. JAMA Neurol 70:1403-1410

140. Williams KL, Topp S, Yang S, Smith B, Fifita JA, Warraich ST, Zhang KY, Farrawell N, Vance C, Hu X, Chesi A, Leblond CS, Lee A, Rayner SL, Sundaramoorthy V, Dobson-Stone C, Molloy MP, van Blitterswijk M, Dickson DW, Petersen RC, Graff-Radford NR, Boeve BF, Murray ME, Pottier C, Don E, Winnick C, McCann EP, Hogan A, Daoud H, Levert A, Dion PA, Mitsui J, Ishiura H, Takahashi Y, Goto J, Kost J, Gellera C, Gkazi AS, Miller J, Stockton J, Brooks WS, Boundy K, Polak M, Munoz-Blanco JL, Esteban-Perez J, Rabano A, Hardiman O, Morrison KE, Ticozzi N, Silani V, de Belleroche J, Glass JD, Kwok JB, Guillemin GJ, Chung RS, Tsuji S, Brown RH Jr, GarciaRedondo A, Rademakers R, Landers JE, Gitler AD, Rouleau GA, Cole NJ, Yerbury JJ, Atkin JD, Shaw CE, Nicholson GA, Blair IP (2016) CCNF mutations in amyotrophic lateral sclerosis and frontotemporal dementia. Nat Commun 7:11253

141. D'Angiolella V, Esencay M, Pagano M (2013) A cyclin without cyclindependent kinases: cyclin F controls genome stability through ubiquitin-mediated proteolysis. Trends Cell Biol 23:135-140

142. Yu Y, Nakagawa T, Morohoshi A, Nakagawa M, Ishida N, Suzuki N, Aoki M, Nakayama K (2019) Pathogenic mutations in the ALS gene CCNF cause cytoplasmic mislocalization of Cyclin F and elevated VCP ATPase activity. Hum Mol Genet 28:3486-3497

\section{Publisher's Note}

Springer Nature remains neutral with regard to jurisdictional claims in published maps and institutional affiliations.
Ready to submit your research? Choose BMC and benefit from:

- fast, convenient online submission

- thorough peer review by experienced researchers in your field

- rapid publication on acceptance

- support for research data, including large and complex data types

- gold Open Access which fosters wider collaboration and increased citations

- maximum visibility for your research: over 100M website views per year

At BMC, research is always in progress.

Learn more biomedcentral.com/submissions 